\title{
Showrooming and Retail Opportunities: A Qualitative Investigation via a Consumer- Experience Lens
}

\begin{abstract}
Showrooming represents a shopper behaviour prevalent in today's retail landscape, referring to consumers inspecting a desired product at a retailer's physical store and then buying it online, usually from a competitor. Showrooming has been examined frequently from a negative standpoint (e.g. free-riding and channel-hopping), via the theoretical lens of multichannel shopping and using a quantitative (theory-testing) approach. The present study seeks to investigate showrooming from a positive standpoint and help retailers to diagnose and appreciate potential opportunities that may be presented by this shopper behaviour. Our investigation is guided by the theoretical lens of consumer experience and a qualitative (theory-building) approach, based on convergent interviews with eleven self-proclaimed showroomers and the shopping context of consumer electronics. The present study contributes to retail theory and practice by illustrating that showrooming can be conceived and managed as a positive shopper behaviour. Its potential opportunities can be better appreciated when retailers consider fully its experiential aspects, such as decision activities and emotions.
\end{abstract}

Keywords: showrooming; multichannel shopping; customer experience; decision activities; emotions 


\section{Showrooming and Retail Opportunities: A Qualitative Investigation via a Consumer- Experience Lens}

\section{Introduction}

Showrooming refers to consumers inspecting a desired product at the physical store of a retailer and then buying it online from another retailer, usually a competitor (Hardgrave, 2013; Teixeira \& Gupta, 2015). It is postulated to stem from the multichannel shopping phenomenon (Gensler et al., 2017; Gensler et al., 2012). Showrooming is widespread and exists in many retail sectors, such as fashion, electrical goods, automobile, and home and garden (PR Newswire, 2012). Its prevalence in the retail landscape can be attributed to several factors, such as expanding choices of products and retailers in the marketplace, a growing number of shopping channels (i.e. store, online, and mobile channels) and increasing usage of mobile devices (e.g. smartphones) for researching and/or shopping (Chiou et al., 2017; Wang et al., 2015). In fact, when showrooming involves the primary use of a mobile device (e.g. smartphone), it is known as mobile showrooming (Tech Insider, 2013).

Market research reports about showrooming are limited, despite its prevalence in today's retail landscape. The few available reports have, nevertheless, offered several insights related to showrooming behaviour (Guruprasad, 2015; Malison, 2015). First, the popularity of showrooming is reported to have a negative effect on bricks-and-mortar stores, especially in developed markets where online shopping is more mature than in developing markets. Between 2009 and 2014, store-based retailing grew 1\% in developed markets, whereas online retailing grew by $15 \%$. Second, consumer electronics and appliances, representing a search product with complex specifications and varied prices, are reported to be showroomed most 
frequently. Conversely, leisure, entertainment and travel services, representing an experience product, are showroomed least frequently. Third, showrooming is fuelled by a combination of environmental factors, such as improved internet connectivity and broadband speeds, continued upsurge of internet retailers, growing number of smaller-sized bricks-and-mortar stores to increase shopping convenience, and increased usage of mobile phone by consumers performing shopping activities. Fourth and final, consumers' reasons for showrooming appear to revolve around the need to experience the product, assess the product in person, find better deals online, gain more information, and talk to a salesperson (Guruprasad, 2015; Malison, 2015).

Bricks-and-mortar retailers often regard showrooming as a threat because of its free-riding and research shopping traits; that is, showroomers 'free ride' (i.e. take advantage of) a bricksand-mortar store to research and experience the desired product. However, showroomers do not buy from the visited bricks-and-mortar store; instead, they purchase the desired product online from another retailer, usually a pure-play retailer (Gensler et al., 2017; Pantano \& Viassone, 2015; Sands et al., 2016). Accordingly, showrooming has been conceived widely as a negative shopper behaviour (Daunt \& Harris, 2017; Rapp et al., 2015). For instance, Daunt and Harris (2017) characterised showrooming as a value co-destructive behaviour whereby shoppers consume the in-store resources of the visited retailer but do not reciprocate by making a purchase. Rapp et al. (2015) examined the negative impact of showrooming on the self-efficacy and coping behaviour of the in-store salesperson. These studies consistently opt for the theoretical lens of multichannel shopping and a quantitative approach to verify the negative characteristics and/or outcomes of showrooming. 
On the contrary, studies on showrooming from a positive standpoint, involving other theoretical lens and a non-quantitative or theory-building approach, are rare in the extant literature. Our current knowledge of showrooming is skewed and incomplete because the extant literature offers very little insight into the extent to which this shopper behaviour can be conceived and managed positively by retailers. In other words, a gap exists in the current knowledge of showrooming with respect to its positive characteristics and outcomes.

The present study seeks to address the gap by investigating three research issues: What decision activities do consumers experience during the showrooming process? What emotions do consumers experience during the showrooming process? What opportunities do the experienced decision activities and emotions denote or connote to retailers? The answers derived from these issues will inform retailers the extent to which showrooming can be conceived and harnessed as a positive consumer behaviour, as well as the extent to which it can be conducive to in-store operations. The present study opts for the theoretical lens of consumer experience and a qualitative (theory-building) approach for guiding the investigation. The present study intentionally avoids the theoretical lens of multichannel shopping and a quantitative approach, which previous studies have typically favoured, in order to shed a more positive light on showrooming behaviour. Our investigation involves convergent interviews with eleven self-proclaimed showroomers based on the context of electronic goods (a product category with high showrooming potential), thematic analysis of the interview data, followed by interpretation of the data to decipher the consumer decisionactivities and emotions pertinent to showrooming, as well as the potential opportunities it may confer to retailers. 


\section{Related literature}

Showrooming represents a shopper behaviour prevalent in today's retail landscape, yet only a handful of studies have examined this shopper behaviour. These studies have consistently approached showrooming from a negative standpoint and can be grouped into three clusters (Daunt \& Harris, 2017; Gensler et al., 2017; Rapp et al., 2015). The first cluster, which most commonly exists in the extant literature, consists of both conceptual and empirical studies focused on the unique nature of showrooming (Chiou et al., 2012; Huang et al., 2009; Kucuk \& Maddux, 2010; Verhoef et al., 2007). For example, in an experimental design, Huang et al. (2009) verified free-riding as an inherent feature of showrooming and that it was more prominent for experience goods than search goods. In a quantitative survey design, Kucuk and Maddux (2010) also established free-riding as a key trait of showrooming driven primarily by the attributes of price and customer service. Their investigation was based on the wallpaper product category. Verhoef et al. (2007), in a conceptual study, discussed research shopping as a defining feature of showrooming and proposed three influential motives, which are attribute-based decision making, lack of channel lock-in and cross-channel synergy. Neslin and Shankar (2009) also echoed the importance of research shopping motives proposed by Verhoef et al. (2007) in explaining their showrooming conceptual work. In a quantitative survey that involved a mixed sample of students and professionals, Chiou et al. (2012) identified five psychological factors underpinning the research shopping aspect of showrooming; these are denial of responsibility, denial of injury, denial of victim, condemning the condemners and appeal to higher objectives. Their investigation focused on automobile and book purchasing.

The second cluster, comprising primarily quantitative studies, devotes attention to the decision outcome and affiliated drivers of showrooming (Gensler et al., 2017; Rapp et al., 
2015). For example, in an online survey based on various product categories (e.g. clothing, shoes, sporting equipment etc.), Gensler et al. (2012) confirmed six categories of factors that significantly influence whether or not consumers decide to showroom. These are perceived benefits; perceived costs, perceived trade-offs; consumer-related variables; shopping-related variables and product-related variables. Balakrishnan et al. (2014) applied an economic model and data to validate the effects of varied cost factors (product cost versus store-traffic cost) on consumers' decisions to showroom. In a survey targeting retail salespersons, Rapp et al. (2015) established the negative impact of showrooming on their self-efficacy and selling performance, as well as their coping and cross-selling behaviours.

The third cluster focuses on the value co-destruction process associated with showrooming (Daunt \& Harris, 2017). In a quantitative survey using a consumer sample, Daunt and Harris (2017) validated four categories of factors that significantly explain the value co-destruction (as opposed to value co-creation) process associated with showrooming. These are product factors (technological speed of change, product acquisition value, product price, and product availability); consumer factors (product involvement, in-store shopping savviness, internet savviness); channel factors (trust in in-store sales employees, trust in online stores, value of in-store shopping, and value of online shopping); and in-store value taking. A summary of the prior research on showrooming is presented in table 1.

Insert Table 1 here 


\subsection{Gaps in the extant literature}

The aforementioned studies have contributed greatly to the extant literature of showrooming by providing the research community with quantitative or empirical knowledge on several key issues. These include i) what showrooming entails in terms of inherent characteristics; ii) how consumers decide to showroom in relation to motivating factors; iii) what negative impact showrooming has on non-consumer stakeholders (e.g. employees); and iv) what the value co-destruction process associated with showrooming entails. Whilst those previous studies have provided us with quantitative or empirical knowledge about showrooming and have shed light on its unique and complex nature, they are not without shortcomings. That is, they have typically examined showrooming from a negative standpoint and conceived it as a threat to retailers. This dominant negative focus on showrooming appears to relate to the theoretical lens of multichannel shopping, which emphasises browsing and switching behaviours across channels (Pantano \& Viassone, 2015; Verhoef et al., 2007). There is a lack of consideration of showrooming via other theoretical lens, such as consumer experience, and therefore results in limited investigation into this shopper behaviour from a positive standpoint.

\subsection{Customer-experience theoretical lens}

The present study adopts the theoretical lens of customer experience as it seeks to shed a more positive light on showrooming. More specifically, it seeks to investigate consumers' decision activities and emotions in the showrooming context (Holbrook et al., 1984; Lofman, 1991; Marks et al., 1988). Consumer experience is a broad discipline; therefore, its measurement is less straightforward and usually consists of multiple components (Grewal et al., 2009). The present study opts for decision activities and emotions as the focal facets of 
customer experience with showrooming because they collectively provide a nuanced understanding of how showroomers behave and feel during the shopping process and, in turn, help identify the moments that can be infiltrated or managed to benefit the retailer (Watkinson, 2013). Personally experiencing and assessing the product has been reported as the major driver of showrooming and more influential than finding a better deal (Gensler et al., 2017; Guruprasad, 2015). Experiencing and assessing the product in person is inherently linked to experiential consumption (Holbrook et al., 1984), further justifying the relevance of the consumer-experience theoretical lens being used for examining showrooming in the present study.

\section{Qualitative method}

In a departure from a quantitative approach previous studies of showrooming have typically favoured (see section 2), we opted for a qualitative approach to address the research issues in order to build further theoretical knowledge of showrooming. More specifically, we preferred a qualitative approach because it helped:

i) To integrate consumers' personal experiences (i.e. decision activities and emotions) into the investigation;

ii) To appreciate there might be more than one reality and varied consumer interpretations of the showrooming experience;

iii) To acknowledge that consumers could not be objectively separated from the investigation as they were intricately linked to the showrooming experience;

iv) To build deeper knowledge, as opposed to testing the existing knowledge, of the showrooming experience (Gordon et al., 2015). 
The research issues guiding the present study are:

- What decision activities do consumers experience during the showrooming process?

- What emotions do consumers experience during the showrooming process?

- What opportunities do the experienced decision activities and emotions denote or connote to retailers?

The qualitative approach consisted of convergent interviews and three decision areas, which are participants and context, data collection and data analysis (Dick, 1990; Gatfield et al., 1999).

\subsection{Participants and context}

The participants were recruited in southwest England (i.e. Bournemouth, Southampton and London) and based on four purposeful criteria, whereby an eligible participant must i) be 18 years or over; ii) own a mobile phone; iii) be an adept mobile shopper, who undertakes shopping activities on the mobile device at least once a week; and iv) have engaged in mobile showrooming activities in the past six months. Data saturation was reached in the eleventh interview; therefore, a total sample of eleven participants was recruited for the present study. The sample size might be considered limited and might diminish the theoretical validity and reliability of the results (Pantano \& Priporas, 2016). Given the study's exploratory nature, the use of a qualitative approach and the lack of consideration of other theoretical lens (see section 2), the sample size was deemed appropriate to provide a catalyst for future studies seeking to illuminate and build deeper knowledge about showrooming (Davis \& McGinnis, 2016). 


\subsection{Data collection}

Convergent interviewing was chosen on three grounds as i) it offered the flexibility of refining the research issues throughout the course of the interviewing process; ii) it employed a funnelling process to elicit agreed perspectives and clarify disagreed perspectives and iii) it consequently helped to refine the subjectivity and enhance the objectivity of the qualitative data (Dick, 1990; Gatfield et al., 1999; Rao \& Perry, 2003; Stokes, 2008). The convergent interviewing process involved three key stages, as displayed in Figure 1.

Insert Figure 1 here

In each interview, a protocol was used to guide the data collection process in order to ensure data reliability. The protocol consisted of eight major open-ended questions that were supported by probe questions. A picture stimulus was also used to complement the interview process in order to help participants concentrate on a targeted showrooming experience and, in turn, ensure the dialogues were purposeful to the research issues under study. The picture stimulus featured several shoppers at a national department store, checking a television model at the physical store and, simultaneously, on various websites (i.e. the official webpage of the department store, Amazon, and eBay). The retail prices varied significantly between those retail channels, whereby the physical store had the highest price, eBay offered the lowest price and the official website and Amazon advertised average prices. The picture stimulus was chosen because consumer electronics and appliances represent a product category that is showroomed frequently (Guruprasad, 2015). 
Example interview questions included: "Looking at the picture, what is the obvious story to you? What is the hidden story?"; "If you were one of the shoppers in the picture, how would you feel about the situation?" and "When facing a choice between a physical store and an online store, which would you prefer to buy a TV from? What are your decision criteria?" These questions were designed to i) ensure that the data would capture realistic perspectives and experiences from the sample of showroomers; ii) provide the interviewer with the flexibility to probe the participants when agreement and/or disagreement arose and iii) consequently, enhance the internal validity of the data (Rao \& Perry, 2003; Riege \& Nair, 2004).

All interviews were conducted face-to-face with the eleven participants, using a semistructured format (Riege \& Nair, 2004). The interviews were conducted within two months on dates agreed with individual participants. Moreover, they were conducted at various public libraries that were easily accessible to the individual participants. Public libraries were chosen because they offered a perceivably neutral, relaxed and safe place for the participants to visit and partake in the interview. On average, each interview lasted around thirty minutes. With the participants' consent, all interviews were audio recorded, transcribed and coded manually by one of the authors within a month of the interview.

\subsection{Data analysis}

The interview data was subjected to thematic analysis, which began with one of the authors independently and manually coding the raw data, according to the procedure proposed by Bazeley (2013). The coding template was developed after considering several sources, which are the research issues under study, the consumer-decision making framework developed by 
Ashman et al. (2015), the consumer-emotions framework developed by Watson et al. (1988) and additional themes emerging from the interviews. Those frameworks were selected because of their sound theoretical underpinning, user-friendliness and nascence to the showrooming context, all of which facilitated the theory-building intent of the present study. The coding template was reviewed and agreed by other authors of the present study prior to development of the final outputs (Richards, 2005).

The thematic analysis involved three phases. More specifically, Phase 1 (open coding) involved coding the transcripts into major interview questions (i.e. "Looking at the picture, what is the obvious story to you? What is the hidden story?"; "If you were one of the shoppers in the picture, how would you feel about the situation?"). Phase 2 (axial coding) involved manually coding the transcripts into pre-defined codes corresponding to the research issues. That is, the first issue concerned the decision activities occurring during showrooming, which included codes for problem recognition, information search, evaluation of alternatives, purchase and post-purchase. The second issue related to the emotions experienced during showrooming, including codes for positive and negative emotions. Phase 3 (developing the framework) involved manually cross-tabulating the codes identified for the decision activities and emotions in order to address the third issue of the potential opportunities offered by showrooming. The results from the thematic analysis are presented in Table 2.

Insert Table 2 here

\section{Results and discussion}


The present study interviewed a sample of eleven self-proclaimed showroomers of both genders, who declared they mobile showroomed at least every six months. The sample consisted of five females and six males who resided in or near southwest England. Table 2 presents the participants' profiles.

Insert Table 3 here

\subsection{Consumer-decision activities}

Ashman et al. (2015) proposed a framework of five groups of consumer-decision activities that potentially underpin the showrooming process, which are problem recognition, information search, evaluation of alternatives, purchase and post-purchase. Our results showed strong and partial support for Ashman et al.'s (2015) framework, whereby showrooming appears to involve four, rather than five, groups of consumer-decision activities. More specifically, problem recognition and information search are likely to occur as a joint or integrated group instead of two separate groups within the showrooming context. The details supporting this are explained in the next section.

\subsubsection{Problem recognition and information search}

Problem recognition may arise in two forms in the showrooming context; namely, one relates to the need to purchase a product and another relates to the need to showroom (Karaatli et al., 2010); the chief interest of the present study is the latter. Accordingly, we asked participants to describe the probable reasons inducing them to showroom in a consumer electronics context. The participants mentioned ease of searching information online, convenience of cross-checking information between retail channels and the opportunity to inspect products 
and/or consult with personnel in-store. Later on, when asked how people searched for information during mobile showrooming, participants identified researching in-store using an internet-connected device, browsing on the retailer's website, researching on search engines and inspecting product options in store.

There appears to be strong overlap between the activities related to problem recognition and information search and, collectively, they correspond to the free-riding and research shopping traits of showrooming (Kucuk \& Maddux, 2010; Verhoef et al., 2007). Purchase uncertainty causes showroomers to conduct an information search at a retailer's physical store to develop knowledge on desired choices, shortlist or filter possible choices or reaffirm preferred choices. Equally, these search activities can also be interpreted as the 'problems' (needs) that trigger showrooming (Balakrishnan et al., 2014). For instance, Participant $\mathrm{H}$ expressed "When you go to the store, [you] examine the products, acquire enough knowledge and information about the products, and then you can purchase online or from a mobile at that store. I [have] done it before with electronics and fashion items." Similarly, Participant K stated "The high value product categories like this TV case involve risks in purchase, so I would prefer both searching online and going to stores to have a better decision." This result suggests the problem recognition and information search stages can occur synchronously within the showrooming context due to buyer uncertainty and the desire to experience the product (Guruprasad, 2015). Buyer uncertainty may stem from knowledge uncertainty, choice uncertainty or a mixture of both (Urbany et al., 1989). Based on this result and related literature, we present the following proposition:

P1: Showroomers will conduct problem recognition and information search activities concurrently, instead of sequentially, due to their buying uncertainty. 
In this decision stage, the participants claimed to frequently visit the retailer's mobile application, the retailer's website and web browsers (e.g. Google), and seek information such as product prices, product descriptions, delivery and payment options, reputation of product brand retailer and customer feedback or reviews. These results suggest that showroomers do not rely on a single source of information; instead, they garner and triangulate varied sources of information to inform or confirm their purchase decisions (Gensler et al., 2012). For example, Participant D stated "Other than price, I would like to look at all the terms relating to delivery, warranty and after-sales service." Participant H stated "I would also have a look at the reputation of the retailers that I might purchase from. Customers' past experiences and online reviews are also very important to provide knowledge about a product or retail business with previous customers." Participant $\mathrm{K}$ concurred "The high value product categories like this TV case involve risks in purchase, so I would prefer both searching online and going to a store to have a better decision." Drawing on this result and related literature, we present the following propositions:

P2: Showroomers will seek and digest information from various online sources, including visiting the retailer's website during the problem recognition and information search activities.

P3: Showroomers will seek and digest both price- and non-price-related information (e.g. customer service support and retailer's reputation) during the problem recognition and information search activities.

\subsubsection{Evaluation}


Ashman et al.'s (2015) framework proposes that evaluation of alternatives, as a consumerdecision stage, generally involves consumers narrowing down the choice of purchase and searching for more information on price, physical attributes, availability and purchase channels. Consumers trying products in-store and browsing products online are also commonly reported at this stage. Consistently, the participants interviewed in the present study also reported weighing up product choices, prices and offline versus online retailers, as well as exploring in-store promotions and payment options to get the best deal at this decision stage. For example, Participant G mentioned "For a purchase like this TV, I will first look at my budget, then product features/functions, warranty terms or quality conditions, the design, and, finally, the payment terms for the purchase." Likewise, Participant $\mathrm{H}$ stated "When in store, I will also look at other models or brands in the same price range but with more functions, or cheaper price but the same benefit package." The participants appeared to apply a range of economic and service-excellence criteria when evaluating shortlisted options. In particular, economic attributes relate to price similarity, price disparity, product features and in-store promotional activities, whereas service-excellence attributes refer to product warranty, after-sales service and payment plan (Mathwick et al., 2001). Evaluating selected choices based on an array of attributes is parallel to a key facet of research shopping; namely, attribute-based decision making (see section 2). Hence, we present the following proposition based on the result and related literature:

P3: Showroomers will shortlist and appraise their desired choices based on a set of economic and service-excellence criteria in their evaluation activities.

\subsubsection{Purchase}


The purchase stage, also known as the choice stage, involves consumers selecting the best option amongst alternatives. The purchase stage is also characterised as a prolonged trial due to the ease of product return in today's retail landscape (Ashman et al., 2015). When deciding on the final choice, the participants interviewed in the present study seemed to rely ultimately on convenience of purchase, speed of purchase and perceived best deal. This result corroborates the funnelling process that takes place at the purchase stage, whereby showroomers start with an array of attributes and choices (the consideration set) at the evaluation stage and then narrow down to a limited few from which they select the best choice (the evoked set) (Comegys et al., 2006).

Our results suggest two major activities underlying the purchase decision when showrooming for a television product, which are value trade-off and price matching. First, value trade-off refers to the likelihood of showroomers buying from an e-tailer if it offers a competitively lower price than the physical retailer. Besides prices, showroomers would also weight their purchase decisions based on other non-price attributes, such as brand reputation and customer service offered by the e-tailer versus the physical retailer. Value trade-off closely corresponds to the e-purchase and store-visit costs discussed by Balakrishnan et al. (2014). Second, price matching refers to showroomers' desires for bricks-and-mortar retailers to proactively and openly communicate and offer price matching. Our results indicated that whilst participants were willing to buy at the physical store, they did not always feel either comfortable or confident in asking for a price match and this might reflect the fact that bargaining practice remains less ingrained and acceptable in British society when compared with Asian societies (Lai \& Aritejo, 2009). 
For example, Participant A expressed "I would not stand forward to ask for [a price match]. I would feel embarrassed and confronted to ask [for a price match]. But if the retailer automatically offers [a price match], I would buy from them, because I will gain benefit, such as no shipping cost which eBay could not offer." Participant E stated "I preferred retailers who initially provide price-matching and I would definitely buy from them as I have all the same conditions plus knowledge from the sales staff." Participant F concurred and stated that "I will choose to buy the TV at the store if they provide price-matching because I don't want to waste more time in searching." This result suggests the strong opportunity potential at the purchase stage whereby retailers can reduce e-purchase and store-visit costs and/or make price matching openly available to customers. Based on the result and supporting literature, we present the following propositions:

P4: Showroomers will make their purchase decision based on the trade-off between economic and service-excellence factors.

P5: Showroomers will be inclined to purchase from visiting a bricks-and-mortar retailer if price matching is offered proactively and openly to them.

\subsubsection{Post-purchase}

The post-purchase stage refers to consumers reflecting on their purchase experience and then acting (or not acting) on this reflection (Ashman et al., 2015). Our results revealed that showroomers are likely to post reviews about the purchase, regardless it is satisfactory or unsatisfactory in nature. Our results also indicated reciprocal behaviour may exist within the showrooming context, whereby consumers post reviews or feedback online as 'return the favour' behaviour for accessing and digesting other customers' reviews at other decision stages (i.e. problem recognition, information search, and evaluation of alternatives). For 
instance, Participant K stated "I am a regular customer of Amazon and depend heavily on its review system. I also post reviews on purchases because it reflects the quality and service of the transaction and might echo the voice of other buyers." We present the following proposition to summarise this result:

P6: Showroomers will share their purchase experiences online, both good and bad, as part of their post-purchase activities.

\subsection{Emotions}

Consumer emotions are rarely discussed or examined in the extant literature of showrooming (see section 2), representing a major gap in the body of knowledge about this retail shopping behaviour. An understanding of consumer emotions, such as how they feel during a shopping process, can provide retailers with a valuable insight to diagnose and design desired shopping experiences (Watkinson, 2013). As the present study seeks to explore the extent to which showrooming offers potential opportunities to retailers, examination of the positive and negative emotions experienced by showroomers was deemed a good fit for the present study. Drawing on Watson et al.'s (1988) framework, our results identified eleven positive and negative feelings participants experienced during the showrooming process. They are excitement, curiosity, disappointment, distrust, cheated, stress, confusion, happiness, hesitance, confidence/controlled and satisfaction (see table 3). Participants did not seem to experience these positive and negative feelings equally in terms of frequency during the showrooming process. Especially in relation to positive feelings, participants seemed to experience happiness and satisfaction more frequently than excitement and confidence. Six of the eleven participants interviewed in the present study expressed a lack of confidence or control during the showrooming process, despite being at the physical store and armed with a 
mobile device, which enabled them to access and digest a wealth of information instantly and effortlessly (e.g. the retailer's website, the competitors' websites, and online reviews). In terms of negative feelings, participants seemed to feel distrust, confused, disappointed, cheated and hesitant more often than stressed.

We cross-tabulated the feelings experienced by participants with the stages of decision activities identified, the results of which suggest the potential existence of goal-directed emotions within the showrooming context (Bagozzi et al., 1999). Participants seemed to experience positive emotions (e.g. curious and excited) primarily at the problem recognition and information search stage, negative emotions (e.g. distrust, disappointed, cheated, confused and stressed) mostly at the evaluation stage, mixed emotions (e.g. happy, controlled and hesitant) at the purchase stage and positive emotions again at the post-purchase stage, as summarised in Table 4. This result suggests the emotions experienced by consumers during the showrooming process are fluid or malleable in nature.

Insert Table 4 here

Positive emotions tend to occur at the problem recognition and information search stage because showroomers learn more about the choices suited to them and thus become more curious and excited about the process (Comegys et al., 2006). For instance, Participant A stated "I would feel curious about how the product looks in reality; therefore, I decided to go to the store and check it." Negative emotions tend to arise at the evaluation stage because showroomers may feel overwhelmed, such as confused and stressed, when they face a range of attractive choices (e.g. prices, product types and after-sales services) offered by the 
physical store and by online retailers. Showroomers may also feel distrust, disappointed and cheated when the retailer they visit (e.g. the physical store and the website) offers varied prices on varied channels (the physical store versus the website) for a similar product.

For example, Participant J mentioned "I would feel confused because there were too many prices and purchase information needs to clarify and compare." Participant I expressed "I would feel disappointed and cheated because the store said it was in a sale, but actually it was not if I put a bit of effort to search online." A mixture of positive and negative emotions may be experienced by showroomers at the purchase stage, whereby they feel happy to find a better deal online but, at the same time, may be hesitant to buy it online. They would have preferred to buy the product at the physical store because of, for example, immediate ownership and/or excellent service; however, the price offered by the physical store is less competitive than the online retailer (Comegys et al., 2006). Positive emotions are likely to occur at the post-purchase stage when showroomers feel they have researched diligently and made the 'best choice'. For instance, Participant K uttered “Overall I feel quite happy and satisfied with this type of purchase because I did research, examined it and chose the best one from what I have seen." Drawing upon the aforementioned results and associated literature, we present the following propositions:

P7: Showroomers will experience a gamut of positive and negative emotions during the shopping process.

P8: The positive and negative emotions will fluctuate between the four stages of decision activities; namely, problem recognition and information search, evaluation, purchase and post-purchase. 


\section{Conclusion}

We have learnt from the extant literature that showrooming can present significant threats to bricks-and-mortar retailers because of its inherent research shopping and free riding nature (Daunt \& Harris, 2017; Gensler et al., 2017; Rapp et al., 2015). Showroomers are characterised as highly price (deal) sensitive and disloyal, and are prone to abandon a bricksand-mortar retailer and buy from a pure-play retailer when they discover a better price (better deal) (Chiou et al., 2012). From the present study, however, we have learnt that these threats from showrooming can be managed and, largely, be converted into opportunities favourable to bricks-and-mortar retailers. To do that, we suggest bricks-and-mortar retailers should diagnose and understand showrooming via the theoretical lens of customer experience, especially in relation to the decision activities and emotions showroomers are likely to experience during the process. We have presented eight propositions to provoke a more experiential and more positive understanding of showrooming in future research.

\subsection{Implications for theory}

The present study illustrates that showrooming can be understood from a positive standpoint and be harnessed as a positive consumer behaviour when other theoretical lens and theorybuilding research approaches are considered. Previous studies have typically examined showrooming from a negative standpoint (e.g. free-riding and channel hopping), via the theoretical lens of multichannel and using a quantitative approach (see section 2). The present study extends the extant literature by investigating showrooming via the theoretical lens of consumer experience and using a qualitative approach. More specifically, we analysed the consumer decision activities and emotions specific to showrooming, which represent two 
under-researched issues or gaps in the extant literature. With respect to consumer decisionactivities, we find Ashman et al.'s (2015) framework relevant for explaining the showrooming process but some amendments are needed. It has its origin in the classical consumer decision-making process proposed by Engel et al. (1968) and consists of the five major stages of problem recognition, information search, evaluation, purchase and postpurchase. We identify four, instead of five, consumer decision-stages are more meaningful for explaining the showrooming process. Problem recognition and information search do not exist as two separate stages but as one joint or integrated stage, whereby their underlying activities intertwine closely. The joint stage of problem recognition and information search encapsulates the research shopping trait of showrooming (Daunt \& Harris, 2017; Gensler et al., 2017; Kucuk \& Maddux, 2010; Verhoef et al., 2007). We also identify consumer decision activities that are more specific to showrooming and some of which are not discussed by Ashman et al. 's (2015) framework.

Guided by Watson's (1988) framework, we identified eleven positive and negative consumer emotions that are meaningful for explaining the showrooming process. They are excitement, curiosity, happiness, confidence/control, satisfaction, disappointment, distrust, cheated, stress, confusion and hesitation. The positive and negative emotions experienced by showroomers appear to be fluid and likely to fluctuate between the various decision stages. More specifically, showroomers are likely to experience positive emotions at the stages of problem recognition/information search and post-purchase, whereas negative emotions occur at the evaluation stage and mixed emotions at the purchase stage. These findings reinforce three theoretical notions about consumer emotions: i) the essential role of emotions in diagnosing a consumption experience (Bagozzi et al., 1999; Watkinson, 2013); ii) the coexistence of positive and negative emotions in a consumption experience, such as 
showrooming (Richins, 1997) and iii) the positive versus negative nature of experienced emotions is closely linked to a consumption goal (Ruth et al., 2002), which can exists in the form of a shopping stage within the showrooming context.

\subsection{Implications for practice}

We seek to inspire retailers to view showrooming from a positive and experiential standpoint in order to develop deeper understanding of this shopper behaviour and greater appreciation of the opportunities it may bring forth. Our study echoes Freeman's notion (2014, p. 1): “If your store is being used as a showroom, make sure that it's your goods ending up being purchased." Distinct from the multichannel shopping lens, the consumer-experience lens encourages retailers to focus on the interaction and experiential aspects a consumer has with showrooming at any point in time, such as the decision activities and emotions experienced during the process (Watkinson, 2013). We illustrate that the consumer decision-activities and emotions complement each other and can be developed into a framework to diagnose the potential opportunities pertinent to showrooming. For example, showroomers are likely to experience positive emotions (e.g. curiosity and excitement) in the problem recognition/information search activity (e.g. experiencing the product and checking online information). Retailers can fruitfully exploit this decision activity by managing in-store and online content to ensure they are matched and user-friendly, offering interactive product experiences and interactive sessions with sales assistants in-store, designing persuasive online content (e.g. product videos and/or social forums) and monitoring competitors' prices and content. 
Showroomers are prone to experience negative emotions (e.g. confusion, stress, distrust and disappointment) in the evaluation activity. Retailers can take advantage of this decision activity by implementing several customer-service strategies. For example, retailers can post authentic peer reviews and offer live chats and/or consultations with sales assistants as sounding boards to help showroomers narrow down their choice sets and, in turn, help minimise confusion and stress. Retailers can also ensure the product information (e.g. prices and/or special offers) displayed in store and online is consistent in order to avert distrust and disappointment arising. These customer-service strategies may enable retailers to lock in and persuade showroomers to transact at the physical store or on the official website.

In the purchase activity, we recommend retailers to synchronise their varied channels (instore and online) to facilitate consumer purchase decisions and focus on convenience, speed and competitive offer. If desirable, we recommend retailers to proactively monitor and match, or outmatch, competitors' prices. If price matching is less desirable, retailers can consider non-price strategies, such as stocking exclusive product ranges or offering bundled deals, to avert price comparison practices. These strategies may help to instil purchase confidence and, in turn, promote purchase happiness in showroomers. In the post-purchase activity, showroomers are likely to experience mixed emotions. We recommend retailers to cultivate showroomers' post-purchase satisfaction by encouraging them to proactively post and share positive reviews, promptly respond to negative reviews and constantly monitor and manage online content of relevant sources (Ashman et al., 2015).

\subsection{Limitations}


The present study contributes to the extant literature of showrooming by examining this prevalent retail shopper behaviour from a positive standpoint, via the customer-experience lens and using a theory-building research approach. However, it is not comprehensive and has several limitations that will provide fruitful directions for future research. First, in comparison with other stages of decision activities, the post-purchase stage associated with showrooming are less thoroughly explored due to the picture stimulus used to facilitate the data collection. The picture stimulus focused primarily on the during-shopping process rather than on the after-shopping process. Future studies can consider the use of multiple picture stimuli that clearly and distinctly illustrate the during- and post-shopping processes associated with showrooming. Second, the sample size used in the present study is considered exploratory and may limit the theoretical generalizability of the results. Future studies can replicate the present study by interviewing a larger and more diverse sample (e.g. varied socio-demographic and/or behavioural backgrounds). Third, the present study has focused mainly on consumers and does not consider the experiences of other stakeholders pertinent to showrooming (e.g. store employees and/or managers). Future studies can help establish the theoretical validity of the research propositions developed by the present study by gauging and triangulating the experiences of customers and non-consumer stakeholders. 


\section{References}

Ashman, R., Solomon, M. R., \& Wolny, J. (2015). An old model for a new age: Consumer decision making in participatory digital culture. Journal of Customer Behaviour, 14, 127-146. doi: 10.1362/147539215x14373846805743

Bagozzi, R., Gopinath, M., \& Nyer, P. (1999). The role of emotions in marketing. Journal of the Academy of Marketing Science, 27, 184-206.

Balakrishnan, A., Sundaresan, S., \& Zhang, B. (2014). Browse-and-Switch: Retail-Online Competition under Value Uncertainty. Production \& Operations Management, 23, 1129-1145. doi: 10.1111/poms. 12165

Bazeley, P. (2013). Qualitative Data Analysis: Practical Strategies. Los Angeles: SAGE.

Chiou, J.-S., Chou, S.-Y., \& Shen, G. C.-C. (2017). Consumer choice of multichannel shopping. Internet Research, 27, 2-20. doi: 10.1108/IntR-08-2013-0173

Chiou, J.-S., Wu, L.-Y., \& Chou, S.-Y. (2012). You do the service but they take the order. Journal of Business Research, 65, 883-889. doi: 10.1016/j.jbusres.2011.06.035

Comegys, C., Hannula, M., \& Väisänen, J. (2006). Longitudinal comparison of Finnish and US online shopping behaviour among university students: The five-stage buying decision process. Journal of Targeting, Measurement \& Analysis for Marketing, 14, 336-356.

Daunt, K. L., \& Harris, L. C. (2017). Consumer showrooming: Value co-destruction. Journal of Retailing and Consumer Services, 38, 166-176. doi: https://doi.org/10.1016/j.jretconser.2017.05.013

Davis, R., \& McGinnis, L. P. (2016). Conceptualizing excessive fan consumption behavior. Journal of Retailing and Consumer Services, 28, 252-262. doi: http://dx.doi.org/10.1016/j.jretconser.2015.10.002

Dick, B. (1990). Convergent Interviewing (Vol. 3). Chapel Hill, QLD: Interchange.

Engel, J. F., Kollat, D. T., \& Blackwell, R. D. (1968). Consumer Behavior. Oxford, England: Holt, Rinehart \& Winston.

Freeman, M. (2014, 15 January). Showrooming: it's an opportunity for retail, not a threat The Guardian, p. 1. Retrieved from https://www.theguardian.com/media-network/medianetwork-blog/2014/jan/15/showrooming-opportunity-retail-threat

Gatfield, T., Barker, M., \& Graham, P. (1999). Measuring communication impact for university advertising materials. Corporate Communications, 4, 73-79. doi: $10.1108 / 13563289910268106$

Gensler, S., Neslin, S. A., \& Verhoef, P. C. (2017). The Showrooming Phenomenon: It's More than Just About Price. Journal of Interactive Marketing, 38, 29-43. doi: 10.1016/j.intmar.2017.01.003

Gensler, S., Verhoef, P. C., \& Böhm, M. (2012). Understanding consumers' multichannel choices across the different stages of the buying process. Marketing Letter, 23, 9871003.

Gordon, R., Gurrieri, L., \& Chapman, M. (2015). Broadening an understanding of problem gambling: The lifestyle consumption community of sports betting. Journal of Business Research, 68, 2164-2172. doi: 10.1016/j.jbusres.2015.03.016

Grewal, D., Levy, M., \& Kumar, V. (2009). Customer experience management in retailing: An organizing framework. Journal of Retailing, 85, 1-14. doi:

10.1016/j.jretai.2009.01.001 
Guruprasad, P. (2015). Showrooming and webrooming: Keeping retail strong for both rural and urban shoppers in the developed world. Passport. Retrieved from //www.portal.euromonitor.com/portal/?YdB\%2bwCAIGCiLWYDji8YCbA\%3d\%3d

Hardgrave, B. (2013). Retail 3.0. RFID Journal, 1-1. Retrieved from http://search.ebscohost.com/login.aspx?direct=true \&db=bth\&AN=97599545\&site=ed $\underline{\text { s-live\&scope }=\text { site }}$

Holbrook, M., Chestnut, R., Oliva, T., \& Greenleaf, E. (1984). Play as a consumption experience: the roles of emotions, performance and personality in the enjoyment of games. Journal of Consumer Research, 11, 728-739.

Huang, P., Lurie, N. H., \& Mitra, S. (2009). Searching for experience on the web: An empirical examination of consumer behavior for search and experience goods. Journal of Marketing, 73, 55-69. doi: 10.1509/jmkg.73.2.55

Karaatli, G., Jun, M., \& Suntornpithug, N. (2010). Investigating mobile services' impact on consumer shopping experience and consumer decision-making. International Journal of Mobile Marketing, 5, 75-86.

Kucuk, U. S., \& Maddux, R. C. (2010). The role of the Internet on free-riding: An exploratory study of the wallpaper industry. Journal of Retailing and Consumer Services, 17, 313-320. doi: http://dx.doi.org/10.1016/j.jretconser.2010.03.003

Lai, M. K., \& Aritejo, B. A. (2009). To Bargain or Not To Bargain? Determinants of Consumer Intention to Bargain in the Retail Market. Advances in Consumer Research - Asia-Pacific Conference Proceedings, 8, 160-161.

Lofman, B. (1991). Elements of experiential consumption: An exploratory study. Advances in Consumer Research, 18, 729-735.

Malison, M. (2015). The global rise of the showroom store. Passport. Retrieved from //www.portal.euromonitor.com/portal/?YdB\%2bwCAIGChkSw45dn3bNw\%3d\%3d

Marks, L. J., Higgins, S., \& Kamins, M. A. (1988). Investigating the experiential dimensions of product evaluation. Advances in Consumer Research, 15, 114-121.

Mathwick, C., Malhotra, N., \& Rigdon, E. (2001). Experiential value: Conceptualization, measurement and application in the catalog and Internet shopping environment. Journal of Retailing, 77, 39-56. doi: 10.1016/s0022-4359(00)00045-2

Neslin, S. A., \& Shankar, V. (2009). Key issues in multichannel customer management: Current knowledge and future directions. Journal of Interactive Marketing, 23, 70-81. doi: 10.1016/j.intmar.2008.10.005

Pantano, E., \& Priporas, C.-V. (2016). The effect of mobile retailing on consumers' purchasing experiences: A dynamic perspective. Computers in Human Behavior, 61, 548-555. doi: 10.1016/j.chb.2016.03.071

Pantano, E., \& Viassone, M. (2015). Engaging consumers on new integrated multichannel retail settings: Challenges for retailers. Journal of Retailing and Consumer Services, 25, 106-114. doi: 10.1016/j.jretconser.2015.04.003

PR Newswire. (2012). 'Showrooming' by Consumers Using Mobile Devices is Transforming Retail Shopping. Retrieved from http://search.ebscohost.com/login.aspx?direct=true \&db=edsgin\&AN=edsgcl.3085455 $43 \&$ site $=$ eds-live $\&$ scope $=$ site

Rao, S., \& Perry, C. (2003). Convergent interviewing to build a theory in under-researched areas: principles and an example investigation of Internet usage in inter-firm relationships. Qualitative Market Research: An International Journal, 6, 236-247. doi: 10.1108/13522750310495328

Rapp, A., Baker, T. L., Bachrach, D. G., Ogilvie, J., \& Beitelspacher, L. S. (2015). Perceived customer showrooming behavior and the effect on retail salesperson self-efficacy and performance. Journal of Retailing, 91, 358-369. doi: 10.1016/j.jretai.2014.12.007 
Richards, L. (2005). Handling Qualitative Data: A Practical Guide. London, United Kingdom: Sage Publications Ltd.

Richins, M. L. (1997). Measuring emotions in the consumption experience. Journal of Consumer Research, 24, 127-146.

Riege, A. M., \& Nair, G. (2004). The diversity of convergent interviewing: Applications for early researchers and postgraduate students. Marketing Review, 4, 73-85.

Ruth, J. A., Brunel, F. F., \& Otnes, C. C. (2002). Linking thoughts to feelings: investigating cognitive appraisals and consumption emotions in a mixed-emotions context. Journal of the Academy of Marketing Science, 30, 44-58.

Sands, S., Ferraro, C., Campbell, C., \& Pallant, J. (2016). Segmenting multichannel consumers across search, purchase and after-sales. Journal of Retailing and Consumer Services, 33, 62-71. doi: 10.1016/j.jretconser.2016.08.001

Stokes, R. (2008). Tourism strategy making: Insights to the events tourism domain. Tourism Management, 29, 252-262. doi: 10.1016/j.tourman.2007.03.014

Tech Insider. (2013). How the mobile "showrooming" threat is changing the retail industry. Business Insider. Retrieved from http://www.businessinsider.com/mobileshowrooming-is-changing-retail-2013-5? IR=T

Teixeira, T. S., \& Gupta, S. (2015). Can You Win Back Online Shoppers? Harvard Business Review, September, 117-121. Retrieved from http://search.ebscohost.com/login.aspx?direct=true\&db=bth\&AN=108820452\&site=e ds-live\&scope $=$ site

Urbany, J. E., Dickson, P. R., \& Wilkie, W. L. (1989). Buyer Uncertainty and Information Search. Journal of Consumer Research, 16, 208-215.

Verhoef, P. C., Neslin, S. A., \& Vroomen, B. (2007). Multichannel customer management: Understanding the research-shopper phenomenon. International Journal of Research in Marketing, 24, 129-148. doi: 10.1016/j.ijresmar.2006.11.002

Wang, R. J.-H., Malthouse, E. C., \& Krishnamurthi, L. (2015). On the Go: How Mobile Shopping Affects Customer Purchase Behavior. Journal of Retailing, 91, 217-234. doi: 10.1016/j.jretai.2015.01.002

Watkinson, M. (2013). The ten principles behind great customer experiences: New York : Pearson Financial Times.

Watson, D., Clark, L. A., \& Teilegen, A. (1988). Development and Validation of Brief Measures of Positive and Negative Affect: The PANAS Scales. Journal of Personality \& Social Psychology, 54, 1063-1070. 
Table 1: Summary of previous research on showrooming

\begin{tabular}{|c|c|c|c|c|}
\hline $\begin{array}{l}\text { Author/s and } \\
\text { year }\end{array}$ & $\begin{array}{l}\text { Research aim and } \\
\text { theoretical underpinning }\end{array}$ & Methodology & Results & $\begin{array}{l}\text { Limitations (with respect to } \\
\text { the present study's research } \\
\text { aim) }\end{array}$ \\
\hline $\begin{array}{l}\text { Balakrishnan } \\
\text { et al. (2014) }\end{array}$ & $\begin{array}{l}\text { A stylised economic model } \\
\text { that incorporates uncertainty } \\
\text { in consumers' valuation of } \\
\text { the product, captures the } \\
\text { heterogeneity among } \\
\text { consumers in their inclination } \\
\text { to purchase online, and } \\
\text { permits product returns; } \\
\text { browse-and-switch } \\
\text { behaviour; trade-offs } \\
\text { between prices and costs) }\end{array}$ & $\begin{array}{l}\text { Economic modelling on } \\
\text { secondary data (e.g. } \\
\text { equilibrium prices and } \\
\text { profits, product costs, and } \\
\text { store traffic costs). }\end{array}$ & $\begin{array}{l}\text { It considered various } \\
\text { equilibrium scenarios for } \\
\text { different combinations of } \\
\text { consumer shopping } \\
\text { behaviours, characterised the } \\
\text { parameter ranges for each } \\
\text { scenario, and demonstrate } \\
\text { that browse-and-switch } \\
\text { behaviour can occur under } \\
\text { equilibrium. It also showed } \\
\text { that the option for consumers } \\
\text { to browse-and-switch } \\
\text { intensifies competition, } \\
\text { reducing the profits for both } \\
\text { firms (online and physical } \\
\text { retailers). }\end{array}$ & $\begin{array}{l}\text { The perspectives and } \\
\text { experiences of consumers are } \\
\text { not considered, specifically, } \\
\text { in relation to their browse- } \\
\text { and-switch behaviours. } \\
\text { It does not specify which } \\
\text { product category the browse- } \\
\text { and-switch behaviour is } \\
\text { based on. } \\
\text { Use of a quantitative research } \\
\text { approach. }\end{array}$ \\
\hline
\end{tabular}




\begin{tabular}{|c|c|c|c|c|}
\hline & & & $\begin{array}{l}\text { that their behaviour is not } \\
\text { serious for a physical book } \\
\text { store versus a car dealership. } \\
\text { Students are more tolerable } \\
\text { with the perceivably } \\
\text { unethical behaviour than } \\
\text { business professionals, and } \\
\text { more likely to neutralise their } \\
\text { behaviour by a belief that } \\
\text { forces beyond their control. }\end{array}$ & \\
\hline $\begin{array}{l}\text { Chiou et al. } \\
\text { (2017) }\end{array}$ & $\begin{array}{l}\text { The effects of the customer- } \\
\text { sales associate relationship, } \\
\text { customers' receptiveness to } \\
\text { online store shopping, and } \\
\text { interaction effects on the } \\
\text { customers' attitude toward } \\
\text { multichannel shopping } \\
\text { behaviour, and the } \\
\text { relationship between } \\
\text { multichannel shopping } \\
\text { behaviour and future } \\
\text { spending intentions; } \\
\text { multichannel shopping }\end{array}$ & $\begin{array}{l}\text { Survey data was collected } \\
\text { from } 231 \text { customers who } \\
\text { purchased cosmetics in } \\
\text { department stores within the } \\
\text { past three months. }\end{array}$ & $\begin{array}{l}\text { The customer-sales associate } \\
\text { relationship significantly } \\
\text { reduces customers' attitude } \\
\text { toward searching offline but } \\
\text { purchasing online. } \\
\text { Receptiveness to online store } \\
\text { shopping significantly } \\
\text { influenced customers' } \\
\text { attitude towards multichannel } \\
\text { shopping }\end{array}$ & $\begin{array}{l}\text { Showrooming is implied } \\
\text { indirectly but not measured } \\
\text { directly. } \\
\text { Does not examine the } \\
\text { experiential aspects (e.g. } \\
\text { decision activities and } \\
\text { emotions) of showrooming. } \\
\text { Other product categories, } \\
\text { besides cosmetics, are not } \\
\text { considered. } \\
\text { Use of a quantitative research } \\
\text { approach. }\end{array}$ \\
\hline $\begin{array}{l}\text { Daunt and } \\
\text { Harris (2017) }\end{array}$ & $\begin{array}{l}\text { The antecedents of consumer } \\
\text { showrooming behaviour, } \\
\text { developed and test a research } \\
\text { model related to } \\
\text { showrooming dynamics; } \\
\text { value co-destruction. }\end{array}$ & $\begin{array}{l}\text { Survey data was collected } \\
\text { from } 275 \text { consumers, } \\
\text { structural equation modelling } \\
\text { was employed to assess the } \\
\text { research model and } 13 \\
\text { associated hypotheses. }\end{array}$ & $\begin{array}{l}\text { Showrooming behaviour is } \\
\text { complex and comprises } \\
\text { differing degrees of } \\
\text { accumulative value co- } \\
\text { destruction and value co- } \\
\text { creation behaviour across } \\
\text { online and offline channels. }\end{array}$ & $\begin{array}{l}\text { Focus on consumers' } \\
\text { perception of showrooming } \\
\text { in general; does not consider } \\
\text { the showrooming behaviour } \\
\text { specific to a product } \\
\text { category. }\end{array}$ \\
\hline
\end{tabular}




\begin{tabular}{|c|c|c|c|c|}
\hline & & & $\begin{array}{l}\text { Consumer characteristics, } \\
\text { channel characteristics and } \\
\text { product characteristics are } \\
\text { established to be associated } \\
\text { with in-store value taking and } \\
\text { online value co-destruction } \\
\text { and co-creation. }\end{array}$ & $\begin{array}{l}\text { Mainly focus on shopping } \\
\text { enjoyment and does not } \\
\text { consider other emotion types. } \\
\text { Use of a quantitative research } \\
\text { approach. }\end{array}$ \\
\hline $\begin{array}{l}\text { Gensler et al. } \\
\text { (2017) }\end{array}$ & $\begin{array}{l}\text { Perceived benefits and costs } \\
\text { of showrooming, and their } \\
\text { effects on consumer decision } \\
\text { to showroom (or not } \\
\text { showroom); trade-off } \\
\text { between benefits and costs. }\end{array}$ & $\begin{array}{l}\text { Survey data was collected } \\
\text { from } 556 \text { respondents, who } \\
\text { were recruited from an online } \\
\text { panel. They were asked to } \\
\text { consider one of the } 10 \\
\text { product categories in relation } \\
\text { to showrooming: clothing; } \\
\text { shoes; sporting equipment; } \\
\text { furniture; toys/games; } \\
\text { kitchen supplies/appliances; } \\
\text { computers; TVs; audio } \\
\text { products; and cameras. } \\
\text { Regression analyses were } \\
\text { conducted. }\end{array}$ & $\begin{array}{l}\text { Average price savings, } \\
\text { perceived dispersion in } \\
\text { online prices, perceived gains } \\
\text { in product quality, and } \\
\text { waiting time in the physical } \\
\text { store are positively associated } \\
\text { with showrooming. } \\
\text { Online search costs and time } \\
\text { pressure are negatively } \\
\text { associated with } \\
\text { showrooming. }\end{array}$ & $\begin{array}{l}\text { Does not consider } \\
\text { experiential aspects such as } \\
\text { decision activities and } \\
\text { emotions. } \\
\text { Use of a quantitative research } \\
\text { approach. }\end{array}$ \\
\hline $\begin{array}{l}\text { Huang et al. } \\
\text { (2009) }\end{array}$ & $\begin{array}{l}\text { The extent to which the type } \\
\text { of information researched, } \\
\text { and the way consumers } \\
\text { search and make choices are } \\
\text { different between experience } \\
\text { and search goods. }\end{array}$ & $\begin{array}{l}\text { Experimental design, which } \\
\text { involved } 90 \text { undergraduate } \\
\text { business students, followed } \\
\text { by the analysis of secondary } \\
\text { data (website visitation and } \\
\text { transaction activity); focused } \\
\text { on three types of search } \\
\text { goods (shoes, furniture, and } \\
\text { garden) and three types of } \\
\text { experience goods } \\
\text { (automotive, health, and }\end{array}$ & $\begin{array}{l}\text { Consumers spend similar } \\
\text { amounts of time online } \\
\text { gathering information for } \\
\text { both search and experience } \\
\text { goods; but, there are } \\
\text { important differences in the } \\
\text { browsing and purchase } \\
\text { behaviour of consumers for } \\
\text { those two types of goods. } \\
\text { Experience goods involve } \\
\text { greater depth (time per page) }\end{array}$ & $\begin{array}{l}\text { Does not focus on consumer } \\
\text { electronics product category. } \\
\text { Whilst it has examined the } \\
\text { free riding aspect, it does not } \\
\text { decipher other inherent or } \\
\text { experiential aspects of } \\
\text { showrooming. } \\
\text { Use of a quantitative research } \\
\text { approach. }\end{array}$ \\
\hline
\end{tabular}




\begin{tabular}{|c|c|c|c|c|}
\hline & & camera). & $\begin{array}{l}\text { and lower breadth (total } \\
\text { number of pages) of search } \\
\text { than search goods. } \\
\text { Free riding is less frequent } \\
\text { for experience than for search } \\
\text { goods. }\end{array}$ & \\
\hline $\begin{array}{l}\text { Kucuk and } \\
\text { Maddux } \\
(2010)\end{array}$ & $\begin{array}{l}\text { The role of the internet in } \\
\text { promoting free-riding } \\
\text { activities, which are } \\
\text { represented by product, price, } \\
\text { and place; free-riding, } \\
\text { consumer purchase stages. }\end{array}$ & $\begin{array}{l}\text { Email survey data was } \\
\text { collected from } 76 \text { senior } \\
\text { independent wall-covering } \\
\text { retail managers. Regression } \\
\text { analyses were conducted. }\end{array}$ & $\begin{array}{l}\text { The internet, and 1-800 } \\
\text { retailers, contribute to retail } \\
\text { free-riding. } \\
\text { Free riding occurs in the form } \\
\text { of consumers accessing more } \\
\text { information on products and } \\
\text { retailers (product), being able } \\
\text { to research and obtain better } \\
\text { deals (price), and making it } \\
\text { easier for them to find } \\
\text { products no matter where } \\
\text { they are available for } \\
\text { purchase (place). }\end{array}$ & $\begin{array}{l}\text { Mainly focus on wall- } \\
\text { covering products. } \\
\text { Whilst it focuses on pre-, } \\
\text { actual- and post-purchase } \\
\text { stages, it does not specify or } \\
\text { decipher what each stage } \\
\text { involves in terms of } \\
\text { underlying activities. } \\
\text { Emotions are not considered. } \\
\text { Use of a quantitative research } \\
\text { approach. }\end{array}$ \\
\hline
\end{tabular}




\begin{tabular}{|c|c|c|c|c|}
\hline & & & & $\begin{array}{l}\text { conceptual, it shows solid } \\
\text { inclination for a quantitative } \\
\text { research approach to address } \\
\text { the proposed issues. Several } \\
\text { equations are included as part } \\
\text { of the discussion, see p. } 76 \text {. }\end{array}$ \\
\hline $\begin{array}{l}\text { Rapp et al. } \\
(2015)\end{array}$ & $\begin{array}{l}\text { The outcomes of } \\
\text { showrooming from a } \\
\text { salesperson perspective; self- } \\
\text { regulation and coping, sales } \\
\text { performance, and cross- } \\
\text { selling. }\end{array}$ & $\begin{array}{l}\text { Email survey data was } \\
\text { collected from } 227 \\
\text { salespersons. Structural } \\
\text { equation modelling was used } \\
\text { to test the research model and } \\
\text { five associated hypotheses. }\end{array}$ & $\begin{array}{l}\text { Negative relationships } \\
\text { between perceived } \\
\text { showrooming and } \\
\text { salesperson self-efficacy and } \\
\text { sales performance, which are } \\
\text { moderated positively by } \\
\text { specific salesperson } \\
\text { behaviours and strategies. }\end{array}$ & $\begin{array}{l}\text { Focus on specialty running } \\
\text { footwear and apparel. } \\
\text { Does not consider } \\
\text { showrooming from an } \\
\text { experience perspective. } \\
\text { Use of a quantitative research } \\
\text { approach. }\end{array}$ \\
\hline $\begin{array}{l}\text { Verhoef et al. } \\
\text { (2007) }\end{array}$ & $\begin{array}{l}\text { Develops and test a research } \\
\text { model related to the causes of } \\
\text { research shopping; trade-off } \\
\text { between search costs and } \\
\text { benefits, and purchase costs } \\
\text { and benefits. }\end{array}$ & $\begin{array}{l}\text { Survey data was collected } \\
\text { from } 396 \text { respondents. Each } \\
\text { respondent were asked to } \\
\text { evaluate one of six } \\
\text { product/service categories: } \\
\text { loans; vacancies; books; } \\
\text { computer; clothing; and } \\
\text { electronic appliances. Factor } \\
\text { and regression analyses. }\end{array}$ & $\begin{array}{l}\text { Empirical testing of the } \\
\text { relationships between four } \\
\text { factors across three channels. } \\
\text { The factors include channel } \\
\text { attributes, channel search, } \\
\text { purchase attractiveness, and } \\
\text { intended channel choice for } \\
\text { search and purchase. The } \\
\text { channels are store, the } \\
\text { internet, and catalogue. }\end{array}$ & $\begin{array}{l}\text { Focus on the trade-off } \\
\text { between costs and benefits in } \\
\text { relation to search and } \\
\text { purchase; does not consider } \\
\text { customer experience. } \\
\text { Use of a quantitative research } \\
\text { approach. }\end{array}$ \\
\hline
\end{tabular}


Table 2: Themes and issues identified from convergent interviews

\begin{tabular}{|c|c|c|c|c|c|c|c|c|c|c|c|}
\hline \multirow[t]{2}{*}{ Themes \& issues identified } & \multicolumn{11}{|c|}{ Participants (pseudonyms*) } \\
\hline & $\mathbf{A}$ & $\mathbf{B}$ & $\mathbf{C}$ & D & $\mathbf{E}$ & $\mathbf{F}$ & $\mathbf{G}$ & $\mathbf{H}$ & $\mathbf{I}$ & $\mathbf{J}$ & $\mathbf{K}$ \\
\hline $\begin{array}{l}\text { Problem recognition \& information } \\
\text { search } \\
\text { 1. } \begin{array}{l}\text { Researching in-store using internet } \\
\text { connected devices }\end{array} \\
\text { 2. Search on retailer website } \\
\text { 3. Search on search engines/apps/competitor } \\
\text { websites } \\
\text { 4. Search about price } \\
\text { 5. Search about product description } \\
\text { 6. Search about customer service and } \\
\text { delivery } \\
\text { 7. Search about payment terms } \\
\text { 8. Search about brand/retailer reputation } \\
\text { 9. Search about other customers' reviews or } \\
\text { comments }\end{array}$ & $\begin{array}{l}\checkmark \\
\checkmark \\
\checkmark \\
\checkmark\end{array}$ & $\begin{array}{l}\checkmark \\
\checkmark \\
\checkmark \\
\checkmark \\
- \\
\checkmark\end{array}$ & $\begin{array}{l}- \\
- \\
x \\
\checkmark\end{array}$ & $\begin{array}{l}- \\
\checkmark \\
\checkmark \\
\checkmark\end{array}$ & $\begin{array}{l}\checkmark \\
\checkmark \\
\checkmark \\
\checkmark \\
- \\
x \\
\checkmark\end{array}$ & $\begin{array}{l}\checkmark \\
\checkmark \\
\checkmark \\
\checkmark\end{array}$ & $\begin{array}{l}- \\
\checkmark \\
x \\
\checkmark\end{array}$ & $\begin{array}{l}\checkmark \\
\checkmark \\
x \\
\checkmark \\
- \\
x \\
\checkmark\end{array}$ & $\begin{array}{l}\checkmark \\
\checkmark \\
\checkmark \\
\checkmark\end{array}$ & $\begin{array}{l}\checkmark \\
\checkmark \\
\checkmark \\
\checkmark \\
\checkmark \\
\checkmark\end{array}$ & $\begin{array}{l}\checkmark \\
\checkmark \\
\mathrm{x}\end{array}$ \\
\hline $\begin{array}{l}\text { Evaluation of alternatives } \\
\text { 1. Price conflict contributes to active } \\
\text { evaluation } \\
\text { 2. Price comparison is a criterion critical for } \\
\text { purchase decision } \\
\text { 3. Customer service influences the choice of } \\
\text { retailer } \\
\text { 4. Comparison of product features to decide } \\
\text { on product/brand choice } \\
\text { 5. In-store marketing activities influence } \\
\text { evaluation } \\
\text { 6. In-store experiences encourage active } \\
\text { evaluation } \\
\text { 7. Added-value/bundled promotion affects } \\
\text { evaluation } \\
\text { 8. Prefer to mix in-store and online channels } \\
\text { for choice evaluation }\end{array}$ & $\begin{array}{l}\checkmark \\
\checkmark\end{array}$ & $\begin{array}{l}\checkmark \\
- \\
- \\
\checkmark \\
\checkmark \\
\checkmark \\
\checkmark\end{array}$ & $\begin{array}{l}\checkmark \\
\checkmark \\
\checkmark\end{array}$ & $\begin{array}{l}\checkmark \\
x \\
\checkmark\end{array}$ & $\begin{array}{l}\checkmark \\
\checkmark\end{array}$ & - & $\begin{array}{l}\checkmark \\
\checkmark \\
\checkmark\end{array}$ & $\begin{array}{l}\checkmark \\
\checkmark \\
\checkmark \\
\checkmark \\
\checkmark\end{array}$ & $\begin{array}{l}- \\
\checkmark \\
\checkmark \\
\checkmark\end{array}$ & $\begin{array}{l}\checkmark \\
- \\
x \\
\checkmark \\
\checkmark\end{array}$ & $\begin{array}{l}\checkmark \\
\checkmark \\
\checkmark \\
\checkmark\end{array}$ \\
\hline
\end{tabular}




\begin{tabular}{|c|c|c|c|c|c|c|c|c|c|c|c|}
\hline \multirow[t]{2}{*}{ Themes \& issues identified } & \multicolumn{11}{|c|}{ Participants (pseudonyms*) } \\
\hline & $\mathbf{A}$ & B & $\mathbf{C}$ & D & $\mathbf{E}$ & $\mathbf{F}$ & $\mathbf{G}$ & $\mathbf{H}$ & $\mathbf{I}$ & $\mathbf{J}$ & $\mathbf{K}$ \\
\hline $\begin{array}{l}\text { Purchase } \\
\text { 1. Inconsistent prices trigger departure from } \\
\text { the physical store } \\
\text { 2. Customers enquiring about price match } \\
\text { 3. Retailers offering price match without } \\
\text { prompting by customers } \\
\text { 4. Price match motivates customers to buy in- } \\
\text { store } \\
\text { 5. Convenience influences purchase decision } \\
\text { 6. Speed influences purchase decision } \\
\text { 7. Secure payment influences purchase } \\
\text { decision } \\
\text { 8. 'Best deal' option influences purchase } \\
\text { decision } \\
\text { 9. Technology savviness influences purchase } \\
\text { decision }\end{array}$ & $\begin{array}{l}x \\
x \\
\checkmark \\
x \\
\checkmark \\
x \\
x \\
\checkmark \\
x\end{array}$ & $\begin{array}{l}\checkmark \\
x \\
\checkmark \\
\checkmark \\
\checkmark \\
\checkmark \\
x \\
\checkmark \\
\checkmark\end{array}$ & $\begin{array}{l}\checkmark \\
\mathbf{x} \\
\checkmark \\
\checkmark \\
\checkmark \\
\checkmark \\
\checkmark \\
\checkmark \\
\mathrm{x}\end{array}$ & $\begin{array}{l}\checkmark \\
\mathbf{x} \\
\checkmark \\
\mathbf{x} \\
\checkmark \\
\checkmark \\
\mathbf{x} \\
\checkmark \\
\checkmark\end{array}$ & $\begin{array}{l}\checkmark \\
\checkmark \\
\checkmark \\
\checkmark \\
\checkmark \\
x \\
x \\
\checkmark \\
\checkmark\end{array}$ & $\begin{array}{l}\checkmark \\
\checkmark \\
\checkmark\end{array}$ & $\begin{array}{l}\checkmark \\
\checkmark \\
\checkmark\end{array}$ & $\begin{array}{l}\checkmark \\
\checkmark \\
\checkmark\end{array}$ & $\begin{array}{l}\checkmark \\
\mathbf{x} \\
\checkmark \\
\mathbf{x} \\
\checkmark \\
\checkmark \\
\mathbf{x} \\
\checkmark \\
\checkmark\end{array}$ & $\begin{array}{l}\checkmark \\
\mathbf{x} \\
\checkmark \\
\checkmark \\
\checkmark \\
x \\
\mathbf{x} \\
\checkmark \\
\checkmark\end{array}$ & $\begin{array}{l}\checkmark \\
\checkmark \\
\checkmark \\
\checkmark \\
\checkmark \\
\checkmark \\
X \\
\checkmark \\
\checkmark\end{array}$ \\
\hline $\begin{array}{l}\text { Post-purchase } \\
\text { 1. Posting reviews online about the purchase } \\
\text { 2. Repeating the showrooming behaviour }\end{array}$ & - & & $\begin{array}{l}x \\
\checkmark\end{array}$ & $\begin{array}{l}\checkmark \\
\checkmark\end{array}$ & $\begin{array}{l}\checkmark \\
\checkmark\end{array}$ & $\begin{array}{l}\mathbf{x} \\
\checkmark\end{array}$ & $\begin{array}{l}\checkmark \\
\checkmark\end{array}$ & $\begin{array}{l}\checkmark \\
\checkmark\end{array}$ & $\begin{array}{l}\mathbf{x} \\
\sqrt{ }\end{array}$ & $\begin{array}{l}\checkmark \\
\checkmark\end{array}$ & $\begin{array}{l}\mathbf{x} \\
\checkmark\end{array}$ \\
\hline $\begin{array}{ll}\text { Emotions } \\
\text { 1. } & \text { Excited } \\
\text { 2. } & \text { Curious } \\
\text { 3. } & \text { Disappointed } \\
\text { 4. } & \text { Distrust } \\
\text { 5. } & \text { Cheated } \\
\text { 6. Stressed } \\
\text { 7. Confused } \\
\text { 8. Happy } \\
\text { 9. Hesitant } \\
\text { 10. } \text { Confident/controlled } \\
\text { 11. } \text { Satisfied }\end{array}$ & $\begin{array}{l}- \\
\checkmark \\
\checkmark \\
- \\
\checkmark \\
\checkmark \\
\checkmark \\
\checkmark \\
\checkmark \\
\checkmark \\
\checkmark\end{array}$ & $\begin{array}{l}\checkmark \\
\checkmark \\
\checkmark \\
\checkmark \\
- \\
- \\
- \\
\checkmark \\
\checkmark \\
\mathbf{x} \\
\checkmark\end{array}$ & $\begin{array}{l}- \\
- \\
\checkmark \\
\checkmark \\
\checkmark \\
- \\
\checkmark \\
\checkmark \\
\checkmark \\
\mathbf{x} \\
\checkmark\end{array}$ & $\begin{array}{l}- \\
\checkmark \\
\checkmark \\
\checkmark \\
\checkmark \\
- \\
\checkmark \\
\checkmark \\
- \\
\checkmark \\
\sqrt{ }\end{array}$ & $\begin{array}{l}\checkmark \\
\checkmark \\
\checkmark \\
- \\
- \\
- \\
- \\
\checkmark \\
\checkmark \\
\checkmark \\
\checkmark\end{array}$ & $\begin{array}{l}\checkmark \\
- \\
\checkmark \\
\checkmark \\
- \\
- \\
- \\
\checkmark \\
\checkmark \\
\checkmark \\
\checkmark\end{array}$ & $\begin{array}{l}\checkmark \\
- \\
\checkmark \\
\checkmark \\
- \\
\checkmark \\
\checkmark \\
\checkmark \\
- \\
\mathbf{x} \\
-\end{array}$ & $\begin{array}{l}- \\
- \\
- \\
\checkmark \\
\checkmark \\
\checkmark \\
\checkmark \\
\checkmark \\
\checkmark \\
\checkmark \\
\checkmark\end{array}$ & $\begin{array}{l}- \\
- \\
\checkmark \\
\checkmark \\
\checkmark \\
- \\
\checkmark \\
\checkmark \\
- \\
\mathbf{x} \\
\checkmark\end{array}$ & $\begin{array}{l}\checkmark \\
\checkmark \\
- \\
\checkmark \\
\checkmark \\
\checkmark \\
\checkmark \\
\checkmark \\
\checkmark \\
\mathbf{x} \\
-\end{array}$ & $\begin{array}{l}\checkmark \\
\checkmark \\
- \\
\checkmark \\
\checkmark \\
- \\
\checkmark \\
\checkmark \\
- \\
\mathbf{x} \\
\checkmark\end{array}$ \\
\hline $\begin{array}{l}\text { Notes: } * \text { Pseudonyms were assigned to protect } \\
\text { Agreed } \checkmark \\
\text { Disagree X } \\
\text { Not mentioned - }\end{array}$ & & & & & & & & & & & \\
\hline
\end{tabular}


Table 3: Participant profiles

\begin{tabular}{|c|c|c|c|c|c|}
\hline $\begin{array}{l}\text { Pseudo } \\
\text { name* }\end{array}$ & Gender & $\begin{array}{l}\text { Showrooming } \\
\text { experiences } \\
\text { (self-reported) }\end{array}$ & $\begin{array}{l}\text { Product } \\
\text { category } \\
\text { reported to } \\
\text { showroom } \\
\text { frequently }\end{array}$ & $\begin{array}{l}\text { Showrooming } \\
\text { frequency }\end{array}$ & $\begin{array}{l}\text { Mobile } \\
\text { device/s } \\
\text { owned }\end{array}$ \\
\hline A & Female & 1 year & Mobile device & $\begin{array}{l}\text { Every four } \\
\text { months }\end{array}$ & Smartphone \\
\hline B & Female & 6 months & $\begin{array}{l}\text { Electronic } \\
\text { appliances }\end{array}$ & $\begin{array}{l}\text { Every six } \\
\text { months }\end{array}$ & $\begin{array}{l}\text { Smartphone, } \\
\text { Tablet }\end{array}$ \\
\hline $\mathrm{C}$ & Male & 6 months & Home furniture & $\begin{array}{l}\text { Every six } \\
\text { months }\end{array}$ & $\begin{array}{l}\text { Smartphone, } \\
\text { Tablet }\end{array}$ \\
\hline $\mathrm{D}$ & Male & 6 months & $\begin{array}{l}\text { Shoes and } \\
\text { clothing }\end{array}$ & $\begin{array}{l}\text { Every six } \\
\text { months }\end{array}$ & Smartphone \\
\hline $\mathrm{E}$ & Male & 6 months & Male grooming & $\begin{array}{l}\text { Every six } \\
\text { months }\end{array}$ & $\begin{array}{l}\text { Smartphone, } \\
\text { Tablet }\end{array}$ \\
\hline $\mathrm{F}$ & Male & 1 year & $\begin{array}{l}\text { Home } \\
\text { appliances }\end{array}$ & $\begin{array}{l}\text { Every six } \\
\text { months }\end{array}$ & $\begin{array}{l}\text { Smartphone, } \\
\text { Tablet }\end{array}$ \\
\hline$G$ & Female & 1 year & Mobile device & Once a year & Smartphone \\
\hline $\mathrm{H}$ & Female & 6 months & $\begin{array}{l}\text { Electronic } \\
\text { appliances }\end{array}$ & $\begin{array}{l}\text { Every six } \\
\text { months }\end{array}$ & $\begin{array}{l}\text { Smartphone, } \\
\text { Tablet }\end{array}$ \\
\hline I & Male & 6 months & Gardening tools & $\begin{array}{l}\text { Every six } \\
\text { months }\end{array}$ & $\begin{array}{l}\text { Smartphone, } \\
\text { Tablet }\end{array}$ \\
\hline $\mathrm{J}$ & Female & 6 months & $\begin{array}{l}\text { Electronic } \\
\text { appliances }\end{array}$ & $\begin{array}{l}\text { Every four } \\
\text { months }\end{array}$ & $\begin{array}{l}\text { Smartphone, } \\
\text { Tablet }\end{array}$ \\
\hline K & Male & 2 years & $\begin{array}{l}\text { Electronic } \\
\text { appliances }\end{array}$ & $\begin{array}{l}\text { Every four } \\
\text { months }\end{array}$ & $\begin{array}{l}\text { Smartphone, } \\
\text { Tablet }\end{array}$ \\
\hline
\end{tabular}

Source: Developed from convergent interviews 
Table 4: Connection between decision stages and emotions

\begin{tabular}{|c|c|c|c|}
\hline $\begin{array}{l}\text { Described } \\
\text { feelings }\end{array}$ & $\begin{array}{c}\text { Negative } \\
\text { emotion }\end{array}$ & $\begin{array}{l}\text { Positive } \\
\text { emotion }\end{array}$ & $\begin{array}{l}\text { Consumer } \\
\text { decision- } \\
\text { stages }\end{array}$ \\
\hline Excited & & $\mathrm{X}$ & $\begin{array}{c}\text { Problem } \\
\text { recognition/ } \\
\text { information } \\
\text { search }\end{array}$ \\
\hline Curious & & $\mathrm{X}$ & $\begin{array}{l}\text { Problem } \\
\text { recognition/ } \\
\text { information } \\
\text { search }\end{array}$ \\
\hline Disappointed & $X$ & & Evaluation \\
\hline Distrust & $\mathrm{X}$ & & Evaluation \\
\hline Cheated & $\mathrm{X}$ & & Evaluation \\
\hline Stressed & $\mathrm{X}$ & & Evaluation \\
\hline Confused & $\mathrm{X}$ & & Evaluation \\
\hline Happy & & $\mathrm{X}$ & Purchase \\
\hline $\begin{array}{l}\text { Hesitant/free to } \\
\text { act }\end{array}$ & $\mathrm{X}$ & & Purchase \\
\hline $\begin{array}{l}\text { Confident or } \\
\text { controlled }\end{array}$ & & $X$ & Purchase \\
\hline Satisfied & & $\mathrm{X}$ & $\begin{array}{c}\text { Post } \\
\text { Purchase }\end{array}$ \\
\hline
\end{tabular}

Source: Developed from convergent interviews 
Figure 1: Convergent interviewing stages of the present study

\section{Introduction}

- Introduction about the picture stimulus \& the interview context

- Introductory questions asking participants to describe \& interpret the meanings of the picture stimulus

\section{Follow-ups}

- Follow the story of the picture stimulus about showrooming

- Open-ended questions to explore the activities \& consumer-decision stages \& associated emotions

- The questions are composed for more probing, sequentially and specifically.

\section{Closure}

- Closing the interview

- Direct questions to query participants' opinions about the implications for managing and overall perceptions about showrooming

Source: Dick (1990) and Rao and Perry (2003) 